The Third Pole: Journal of Geography

Vol. 20 - 21: 47-58, 2021

DOI: https://doi.org/10.3126/ttp.v21i01.41617

Department of Geography Education,

Central Department of Education, T.U., Kathmandu, Nepal

\title{
Vulnerability Assessment of Squatter Settlement in Butwal Sub-Metropolitan City, Nepal
}

\section{Abstract}

\author{
Manoj Marasini ${ }^{1}$, Chhabi Lal Chidi' ${ }^{1,}$
}

Squatter settlement is uncontrolled and unplanned settlement consisting of dwelling built on land that is not owned. Squatters are the most vulnerable groups being very poor. This paper assessed the extent of socio-economic characteristics, causes of being squatters, vulnerability and their adaptation strategies of Sundarbazar area in Butwal. The descriptive analytical methodology was employed to generate data from both primary and secondary data sources. Out of 339 households, 113 households were selected through a systematic random sampling procedure. Field observation, focus group discussion and personal interviews were also applied to collect primary data. The squatter settlement in the study area has inadequate accommodation, poor access of safe water, sanitation, unmanaged waste disposal system and polluted environment. Poor economic condition, unemployment, and natural disaster along with availability of free land are the major cause of being squatters in this region. Furthermore, risk of health hazard, unemployment, and income uncertainty are the vulnerability of squatter people in the study area. It is concluded that poverty reduction in both rural and urban area can solve this problem but providing income generation opportunities, basic service facilities are major concern at present. In the developing countries like Nepal, squatter settlement is less known in literature and curriculum of formal education. Thus, it requires to aware new generation through school education system and the higher level for better urban planning and management in the future.

Keywords: Squatter settlement, vulnerable groups, income uncertainty, service facilities and environmental deterioration.

1 Chidi is a Lecturer, Central Department of Geography, Tribhuvan University, Corresponding email: chidichhabilal@gmail.com 


\section{Introduction}

Squatter is an unplanned and uncontrolled settlement consisting a dwelling built up on land that is no legally owned or rented by the settlers. Thus, squatter settlements are those areas where poor people live without any legal provision. It is being one of the major problems in the $21^{\text {st }}$ century of the cities of developing countries. Squatter settlement is an increasing phenomenon with rapid urbanization process in most of the South Asian countries. Increase of poor living condition in squatter settlement is being highly questionable for this region (Baral, 2019; Hurely, 1990). Large number of people pushed by different unfavorable condition in their place of origin, although, they are not interested to leave their birthplace. They have migrated from their homeland in search of alternative livelihood opportunities (Acharya, 2011). Due to different environment, many migrated people concentrates to marginal land of urban chore for their livelihood. Squatter people are concentrated on high-risk marginal land. Marginal lands are generally flood risk area, poor accessible, zone of health hazard etc. They have poor quality of residential and the working environment associated with unhealthy environment (Ooi \& Phua, 2007). People change original livelihood strategies that has been making more difficult to survive them in the urban environment. Thus, squatter people live in a very deplorable condition having access to basic services (Zerbo et al., 2020; Kellett, 2011). This type of settlement is termed Sukumbasi in Nepal (Sharma, 1998). Poor peoples of urban areas have to face many problems like limited access to employment opportunities, income, inadequate and insecure housing and services. They have to face problems of violence, unhealthy environment, and limited access to adequate health and education facilities (World Bank, 2003; DFID 1998; DFID 2002). Many rural farmers of poor living condition have to struggle for their livelihood. Unemployed and deeply rooted rural poor people come to urban area in search of employment (Bhattarai, 2001; Bhattarai, 2005). People living in squatter settlements are struggling for their survival with low quality of living condition. Squatter settlement is being a major issue in Kathmandu during the last two decades as in other large cities in developing countries. It is because of the rapid population growth by migration and uncontrolled urbanization (Madai, 2006). During this period, the increasing condition is not only in the capital city of Kathmandu (GovN, 2021; MoHP, 2011; GovN, 1996) but also in many other cities of Nepal like Butwal. The overflow of migration and uncontrolled urbanization in the cities of Tarai region including Butwal (BSM, 2015) are also facing similar problems of increasing squatter settlements with poor living condition but neither government nor concerned agencies have fully aware in this aspect. Thus, this paper aims to assess socioeconomic status, vulnerability and their adaptation strategies of squatter settlement of Butwal Sub-metropolitan city of Nepal. Furthermore, information about the real situation of squatter settlement is directly linked with awareness which are transferred 
though formal education system and training for action to solve the problem (Shaw et al., 2011). Natures of vulnerabilities of squatter settlements are not similar in all countries. Thus, the finding of this study will be helpful to make aware about the squatter settlement of Butwal and Nepal as well, which will be helpful for future planning for sustainable urban development.

\section{Methods and Materials}

Urban area of Butwal is located at the Tarai plain area at the foothill of Siwalik. However, its administrative area is extended toward the north at the ridge top of Siwalik. Butwal Sub-metropolitan area is intersected by Mahendra highway (east west) and Siddhrtha highway. Total area coverage is $101.61 \mathrm{~km}^{2}$ and divided into 19 wards having total population 138742 in 2011 (CBS, 2012). Tianu River flows through the central part of Butwal from north to south dividing approximately into two equal parts (Figure 1).The selected squatter settlement for this study is Sundernagar. It is located in the Butwal Sub-metropolitan city, ward number 8, along the eastern part of Tinau River. Among many squatter settlements in Butwal, Sundernagar was settled in 2004 during the period of Maoist insurgency.This settlement is located at 166 meter altitude from the sea level. In the beginning, there were small huts facing environmental and institutional problems but now there are altogether 339 households having 1421 population, among them 692 are male and are 729 female.

This research is based on both primary and secondary data source. Secondary source of information was derived from published and unpublished reports and research articles. Secondary information was collected from libraries, concerned offices and websites. Primary information was collected from the field survey. Before detail field survey, map of the study area and preliminary observation were done. Among total 339 households in Sundernagar settlement, only 113 households were selected for household survey. At first, all household were listed having with serial number and the name of the household head. One household was randomly selected using snowball sampling method. Systematic sampling method was adopted selecting each third household from the listed households. 


\section{Figure 1: The study area}

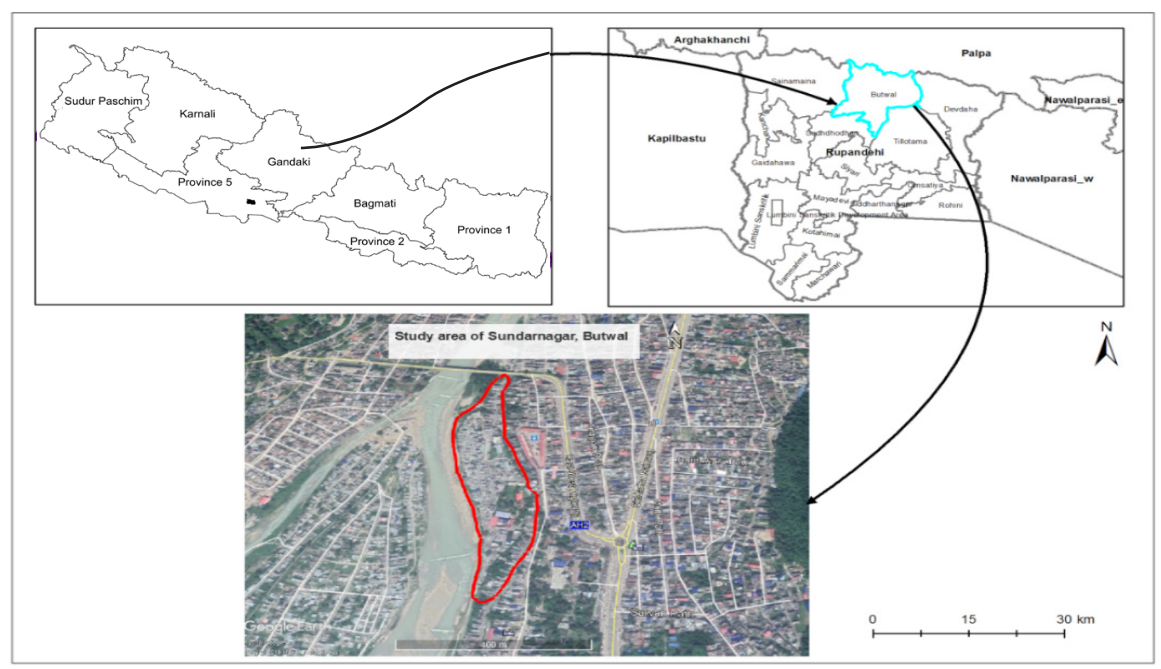

Structured questionnaire was used for household survey (Alder 1994; Hart 2005). One Focus Group Discussion (FGD) were conducted in the settlement and 15 Key Informant Survey (KIS) were conducted with old person and knowledgeable persons in the selected settlements and concerned officials. Informal discussion and field notes were prepared to derive additional information as per requirement. This study is mostly descriptive analysis (Kitchin and Tate 2000) except some quantitative socioeconomic data.

\section{Results and Discussion}

Socio-economic Status: Socioeconomic condition includes population composition, marital status, educational status, dependency of population, and occupational status the sampled households in the study area.

Population composition: Age and sex structure of the population is the most important variable in the study of mortality, fertility migration and other social phenomena. The total population of surveyed household is 501. Among them 248 (49.5\%) are male and $253(50.49 \%)$ are female. Male population is slightly less than female population, which is similar to the national situation (CBS, 2011) 


\section{Table 1: Broad age and sex composition}

\begin{tabular}{|l|c|c|c|c|c|c|}
\hline Age Group & Male & Percent & Female & percent & Total & Percent \\
\hline Below 15 & 74 & 29.84 & 80 & 31.62 & 154 & 30.7 \\
\hline $16-59$ & 159 & 64.11 & 156 & 66.66 & 315 & 62.87 \\
\hline 60 above & 15 & 6.05 & 17 & 6.72 & 32 & 6.39 \\
\hline Total & 248 & 100 & 253 & 100 & 501 & 100 \\
\hline
\end{tabular}

Source: Field survey, 2015

Population was categorized into three broad age groups (Table 1). The highest number of population is under the age group of 16-59. Generally, this age group recognized as a working age (economically active population) group. Therefore, this age group stands for the working population. The dependency ratio is $59.04 \%$ in the study area.

Marital status of respondents: Marriage is a social phenomenon as well as defined as legally union of two person of inverse sex. Marital status is demographic character, which effects on the population growth of a country. The marital status differs in term of social group, individuals, societies, inter castes marriage, unmarried, widow/ widowers and separated are included in marital status.

Figure 2: Marital status of squatters

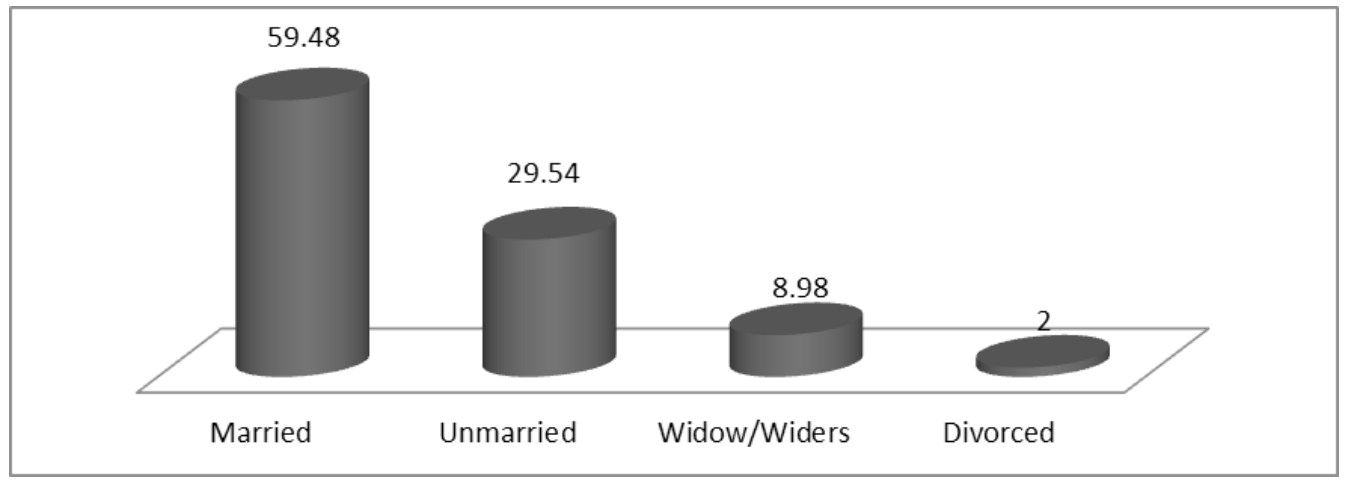

Source: Field Survey, 2015.

In sampled household, $59.48 \%$ people are married and $29.54 \%$ are unmarried. Similarly, $8.98 \%$ are widow/widowers and $2 \%$ are divorced (Figure 2). Most of the household heads state that arranged marriage is dominant in the society. However, inter-caste and love marriages are becoming common in recent past. 
Educational status: Literacy is an ability to read and write which is considered as a main factor for the development of individual and a country as well. Locating proximity to urban area, it has a number of educational institutions operating different level of educational in their locality.

Figure 3: Educational Status

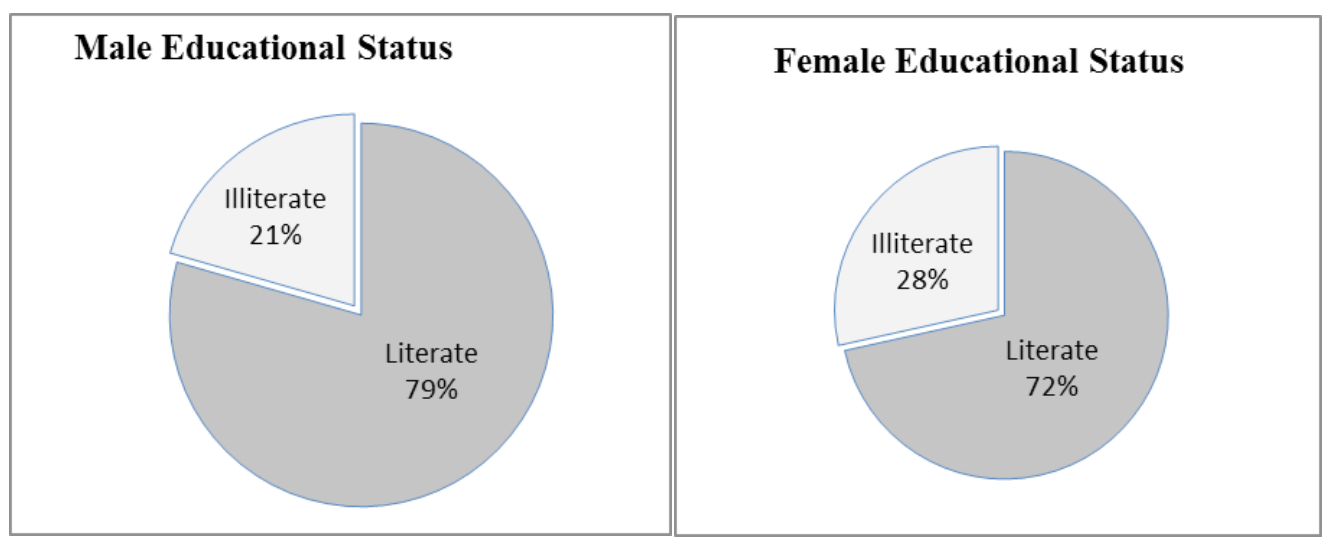

Source: Field Survey, 2015

Contrast to proximity of educational institution, poor economic condition in their origin, hinders squatter people and their children to get quality education opportunities. The literacy rate of the study area is well- satisfactory where male literacy is $75 \%$ and female literacy is $72 \%$ having average literacy rate is $75.45 \%$ (Figure 3 ) which is quite higher than that of national average $66 \%$ (CBS, 2011). Higher literate proportion in the settlement may be due to easy accessible of educational institutions with affordable fee structure.

Dependency of population: The dependent population includes children, student and housewives. They are $56.89 \%$ of total sampled households. Those people who are involved into different types of income generating activities are called incomegenerated population. They are $43.11 \%$ of total population of sampled households. Male proportion is quite higher than that of female in income generating population, which is similar to national scenario. 
Manoj Marasini \& Chhabi Lal Chidi / Vulnerability Assessment of Squatter Settlement in Butwal...

|| $53 \|$

Table 2: Dependency and income generated population in the study area

\begin{tabular}{|l|c|c|c|c|c|c|}
\hline \multirow{2}{*}{ Population } & \multicolumn{2}{|c|}{ Male } & \multicolumn{2}{c|}{ Female } & \multicolumn{2}{c|}{ Total } \\
\cline { 2 - 7 } & Population & Percent & Population & Percent & Population & Percent \\
\hline Dependent & 118 & 47.6 & 167 & 66.0 & 285 & 56.89 \\
\hline $\begin{array}{l}\text { Income } \\
\text { generated }\end{array}$ & 130 & 52.4 & 86 & 34.0 & 216 & 43.11 \\
\hline Total & 248 & 100 & 253 & 100 & 501 & 100 \\
\hline
\end{tabular}

Source: Field survey, 2015

Economically dependent population is nearly $57 \%$ of the total population on $43 \%$ income generating population. Income generating populations are involving into different economic activities. Proportion of male on income generating population is quite higher than that of female. Inversely, female proportion has outnumbered male on dependent population (Table 3). It is because of the female have to involve more time in household work than male. Therefore, they have less time to involve in income generating activities.

Occupational status: Occupation indicates the socio economic status of the people of squatter settlement. Different types of occupation are possible to support livelihood strategies of squatter households. The squatter people have engaged into various kinds of occupational in order to meet their livelihood.

The higher proportions of income generating peoples are unskilled labor $37.96 \%$ followed by private business $18.05 \%$ and skilled workers $9.72 \%$. Rickshaw/thela pullers are approximately $8.33 \%$ of total employed population. Some people are also in government sector but their proportion is very low (Figure 4). They have involved in different sectors even in skilled workers but their proportion is low in total income generating activities and most of them are in the lower post. Nature of employment indicates that they have lower income from their income generating activities as compared to other areas reflecting poor livelihood condition of the squatter settlement. 
Figure 4: Occupational structure in the study area

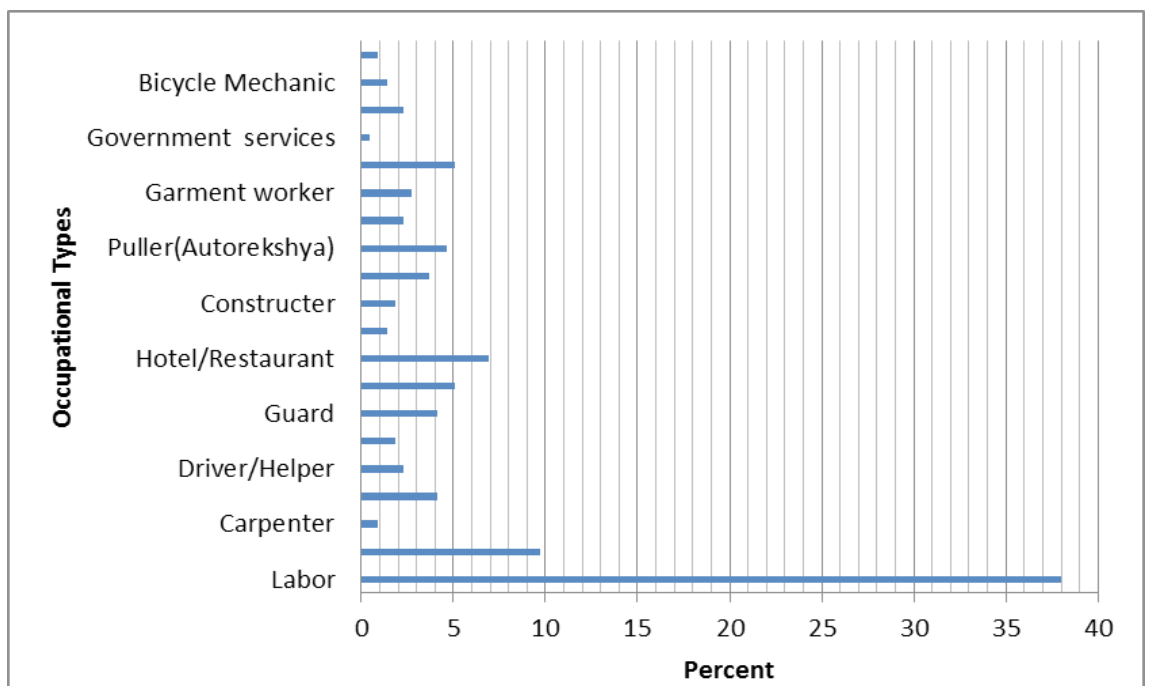

Vulnerability: Vulnerability means the insecurity of wellbeing of individuals or communities in the face of changing environment (ecological /social/economic/ political) in the form of sudden shocks, long-term trend seasonal cycle (Moser, 1996; Madai, 2006). During the field survey, the researcher has found many factors that create vulnerability in people's life in Sundernagar squatter settlement, which are described below.

Natural hazard: A natural hazard is a naturally occurring event that might have a negative effect on people or the environment (Wikipedia). Many natural hazard problems exists in the study area flood and storm are major natural hazard in the study area during the rainy season frequent flood swept dozens of houses however they cannot leave that place due to their economic condition.

Poor housing status: People in Sundernagar do not have legal right on land where they have made the house for shelter. Houses are made up of block and CGI roof of less investment. However, houses are agglomerated and compact. These houses are unstable in case of any hazards occurs like flood, wind, storm and earthquake. Before the establishment of this settlement, that locationwas a disposal site of municipal waste. This site is unstable with loose soil materials composition. Thus, the foundation of the houses is not be strong and the houses vibrates when the vehicle are riding on the road.

Poor health condition: In the study area, the risk is noted clearly in health condition of people, which affects the livelihood of the people. Firstly, they are not able to have nutrition foods due to poor economic condition. Secondly, they are not able to have 
good access to treatment. Thirdly, most of the squatters have low income. Therefore, they always want to engage in their work. They have very limited time to take care their children and their health. Thus, they are facing deteriorating of health condition. Most of the people are suffering from many common diseases like headache, stomachache, fever, allergy, common cold, cough and fever. They are also suffering from the mental health problems, body ache, diabetes, pneumonia, Jaundice, kidney stone etc. These are prevailing in the study area are due to low access of clean drinking water, poor sanitation and polluted environment by noise and dust.

Sanitary condition: The study area is located at the bank of river and the beside city area. So, the river also polluted due to connection of drains, which are like a dumping site. Many people and children use river water for different purpose. Due lack of water facility within settlement, most of the household have not used their own toilet and defecate near riverbank at open place.

Poor drinking water facilities: Water facility is not sufficient in a whole settlement. Only $40 \%$ households use private taps for drinking purpose while, $60 \%$ households use public tape. There are only five public tapes available within settlement where supply of water is limited for 2 hours per day (morning and evening). It is very difficult to manage the water due to their working time. Therefore, most of the dwellers use river water for drinking and other use. This is not secure for drinking purpose although they do not practices any water treatment facility for drinking purpose.

Environment pollution: Environment condition is also a major factor to determine the vulnerability of squatters in the study area. Environment condition of the study area was found to be poor in terms of solid waste management, air pollution and noise pollution. It was observed that, drainage and other waste disposal are directly disposed in Tinau river and open channel which ultimately affected the settlement area. Squatter people live nearby vegetable garbage and hospital area where the people face bad smelling and odor. This settlement is located near bus park area where noise pollution through vehicle frequently observed. Sanitation is worse in this area where open deficit along with unmanaged pig farming create surrounding environment highly polluted. Furthermore, inhabitants are highly affected by dead bodies of the animal and funeral ceremony of human beings. Similarly, untreated effluent from factories are also disposed into the river is also deteriorating quality of water. Squatter people are living here with unhealthy and degraded environment, which leads to the emergence of very risky disease in any case.

Socio-economic vulnerabilities: Absence of the formal employment, low income, poor housing conditions have created many socio-economic crises in the study area. Being unskilled and low education labor compelled them to face limited option in 
their working field like construction work, puller, mason, painters etc. Beside this, lack of awareness, discrimination, agglomerated with compact settlement is increasing vulnerability within the society. During leisure time, they get involved in the playing cards, carom board especially in futile work. Doing by a job some of the neighbors and people get intoxicated and quarrel with each other. Being composition of different caste/ ethnic groups, sometimes-social conflict exists within the squatter settlement. Another big problem is drug abuse among the teenagers group. Likewise, different kinds of people visit from outside the community polluted by violence and over run by gang fights in some case. In such societies, there might be theft problems make them more vulnerable.

Institution and vulnerability: Sundernagar squatter is settling haphazardly nearby riverbank, which is highly susceptible to flood hazard. Damage and loss of property by flood is usual in summer rainy season. Local administration always warns to leave that place and tried to remove them using security personals. However, squatter people do not have choice to leave this place because of poor economic status. Residents of the squatter frequently demand for their basic service facilities but municipality does not allocate budget due to illegal settlement.

The Risk of the unemployment: The squatter people in the study area have limited income oppertunities. Most of them have low income and irregularities of income source.Most of the people are unskilled. People engaged in different sector but not permanent. Most of the worksare informal sector and low income categories. Even literate people are not able to get appropriate job. They are engaged in different low-income activities.

Education for awareness: Squatter settlement and their vulnerability is being a major challenge of urban area of developing region to which concerned people need to be aware (Momade and Hainin, 2018). The vulnerability situation of the squatter settlement of Sunderbazar in Buwal is similar to other squatter settlement in developing countries in the world. Thus, it requires making aware for new generation about this dark side of the urbanization process in Nepal. School based education system is the best way to make aware (Shiwaku and Fernandez, 2011) which will help to take attention in this sector of urban area for better urban planning and research in the future. Thus, it needs to be added in the curriculum of social studies in school and higher level as well.

\section{Conclusions}

Poor socio-economic status and high vulnerability of the people living in Sundernagar squatter settlement is similar to other squatter settlement of other cities in Nepal and regions of developing world. The literacy status is quite higher than that of national 
average in this squatter settlement although socioeconomic status is not satisfactory. They are suffering from flood, poor housing status, health problems, poor sanitary condition, environmental pollution, and poor access to health and education facility. Furthermore, risk of unemployment, income uncertainty and indebtedness are additional vulnerabilities. The settlement has worse environment condition in terms of land, water and air pollution. It is concluded that squatter requires land entitlement, skill base training, knowledge of education and social awareness to enhance their physical, mental, social and economic assets and improve their livelihood strategies. Therefore, it requires seriousness of concerned stakeholders to reduce the urban poor. Furthermore, this study is one of the most important evidence and situation of urban poor, which needs to aware to new generation. Student should be made aware about this dark side of the urbanization process like squatter settlement of developing world. Thus, it needs to include in the school level curriculum in social studies.

\section{References}

Acharya, B. R. (2011). Urban poverty: A sociological study of Shankhamul squatter. Dhaulagiri Journal of Sociology and Anthropology, Vol. 4, pp. 179-192. doi: 10.3126/dsaj.v4i0.4519

Alder, P.A. (1994).Observational techniques in handbook of qualitative research. New Delhi: Sage Publication.

Baral, C. R. (2019). The status of livelihood vulnerability and its coping capacities of urban squatters in Kathmandu Metropolitan City, Nepal. Patan Pragya, Vol. 5 (1), pp. 19-32.

Bhattrai, K.P. (2001). Rickshaw pulling as a way of earning livelihood, Birtamod Jhapa. (Unpublished M.A. thesis). Central Department of Geography, Tribhuwan University, Nepal.

Bhattarai, K. P. (2005). Livelihood strategies of squatter households in an urban environment: A case study of Kathmandu Metropolitan City, (Unpublished PhD Dissertation). Norway: Geography Department, University of Bergen.

BSM (2015). Butwal (2071/72): Annual report. Butwal: Butwal Sub-Metropolitan (BSM) city.

CBS, (2011). National sample census of Kathmandu. Kathmandu: Central Bureau of Statistics (CBS).

DFID (1998). Sustainable livelihood guidance sheet, Livelihoods DFID, Government of U.K. DFID (2002) Sustainable livelihood guidance sheet, Livelihoods DFID, Government of U.K.

GovN (1996). National shelter policy in Nepal. Kathmandu: Department of Housing and Urban Development (DHUD), Government of Nepal.

GovN (2021). Land reform act 2021. Kathmandu: Ministry of Land Reform and Management, Government of Nepal. 
Hart, C. (2005). Doing your master dissertation, New Delhi: Vistaar Publication, New Delhi.

Hurley, D. (1990). Income generation schemes for the urban poor (Development guideline), (4).Oxford: Oxfam, 274 Banbury Road, Oxford OX2 7DZ

Kellett, P. (2011). Informal settlement Processes in Latin America. In: H. Santosa, L. A. Bustillos and M. Napier (Eds.), Sustainable livelihood in informal settlements (CIB Report, Publication 302), pp 15-24.

Kitchin, R. \& Tate, N. J. (2000). Conducting research in human geography: Theory, methodology and practice. London: Pearson Education Limited.

Madai, P.B (2006). Livelihood strategies of urban of poor: A case study of squatter settlement at Balaju, Kathmandu (Unpublished M.A Dissertation). Kathmandu: Central Department of Geography, Tribhuvan University.

MoHP (2011). Statistical information of Nepal, 2011.Kathmandu: Ministry of Health and Population.

Momade, M. H. and Hainin, M. R. (2018). Problems affecting squatter settlements in Nampula, Mozambique. International Journal of Engineering and Technology, Vol. 7(4), pp. 5022-5025. doi: 10.14419/ijet.v7i4.26560

Moser, C. (1996). Confronting crisis: A comparative study of household responses to poverty and vulnerability in four urban, communities, Washington D.C: ESD.

Ooi, G. U. and Phua, K. H. (2007). Urbanization and slum formation. Journal of Urban Health, Vol. 84, pp.27-34. doi: 10.1007/s11524-007-9167-5

Sharma, R. P. (1998). Squatter settlement in Bhaktapur Municipality (Unpublished MA Thesis). Central Department of Geography, Tribhuvan University, Kathmandu, Nepal.

Shaw, R., Takeuchi, Y., Gwee, Q. R. and Shiwaku, K. (2011). Disaster education: An introduction. In: R. R. Shaw, K. Shiwaku and Y. Takeuchi (Eds.), Community, environment and disaster risk management: Disaster education, Vol. 7, pp.122. Kyoto: Emerald-Publishing House.

Shiwaku, K., Fernandez, G. (2011). Innovative approaches indisaster education: An introduction. In: R. R. Shaw, K. Shiwaku and Y. Takeuchi (Eds.), Community, environment and disaster risk management: Disaster education, Vol. 7, pp. 1-22. Kyoto: Emerald-Publishing House.

World Bank (2003).Poverty reduction and economic management, Report Document South Asia Region, World Bank.

Zerbo, A., Delgado, R. C. and González, P. A. (2020). Vulnerability and everyday health risks of urban informal settlements in Sub-Saharan Africa. Global Health Journal, Vol. 4 (2), pp. 46-50. https://doi.org/10.1016/j.glohj.2020.04.003 